\begin{tabular}{c|c|c}
\hline \hline & MARINE ECOLOGY PROGRESS SERIES \\
Vol. 228: 213-226, 2002 & Mar Ecol Prog Ser & Published March 6 \\
\hline
\end{tabular}

\title{
Use of back-reef and lagoon habitats by coral reef fishes
}

\author{
Aaron J. Adams*, John P. Ebersole \\ Biology Department, University of Massachusetts Boston, 100 Morrissey Blvd, Boston, Massachusetts 02125, USA
}

\begin{abstract}
We visually censused fishes along transects on the back-reef and adjacent lagoons of bank-barrier reefs at 6 sites on St. Croix, US Virgin Islands, to determine the extent to which coral reef fishes use lagoon habitats as nurseries. Fishes were recorded by size class (small, $<3 \mathrm{~cm}$; medium, 3 to $5 \mathrm{~cm}$; large, $>5 \mathrm{~cm}$ ) on the back-reef, and on 5 lagoon habitat types: patch-reef, rubble, seagrass, algal plain, and sand. We examined densities of 4 focal 'species' (Acanthurus spp. [A. bahianus and A. chirurgus], Haemulon spp. [all species of the Haemulon genus], Sparisoma aurofrenatum, and Scarus iserti), and densities of all species combined to determine spatial and temporal patterns of habitat use. Although there was a general tendency for coral reef fishes to use lagoon habitats as nurseries, we discerned 2 patterns of habitat use: 1 group, exemplified by Acanthurus spp. and Haemulon spp., use lagoon patch-reef and rubble as nurseries in preference to back-reef and other lagoon habitats; in contrast, Sparisoma aurofrenatum and Scarus iserti preferentially use back-reef and, to a lesser extent patch-reef, as nursery, juvenile, and adult habitat. Temporal variation was greatest in the small size class and least in the large size class. Most settlement occurred during summer, which is when settlement in lagoon habitats was greatest, with a little settlement in winter in the back-reef habitat. For species that use lagoons as nurseries, lagoon habitats must provide advantages that offset the additional energy expense and predation experienced by both incoming larvae, as they cross over the reef and search for patch-reef and rubble, and juveniles, as they return to the reef during the juvenile-to-adult transition. Given the use of lagoon habitats as nurseries, there is a need for inclusion of lagoons in coral reef reserves.
\end{abstract}

KEY WORDS: Nursery $\cdot$ Post-settlement $\cdot$ Lagoons $\cdot$ Seagrass $\cdot$ Patch-reef $\cdot$ Rubble $\cdot$ Ontogenetic habitat shift · Juvenile

\section{INTRODUCTION}

The life history of most coral reef fishes is a 2-phase cycle: juveniles and adults are demersal, while larvae are planktonic. Furthermore, larvae of many of the more prominent fish taxa on coral reefs settle into habitats that are distinct from those of adults (Robertson et al. 1979, Shulman \& Ogden 1987, Robertson 1988), creating another stage within the demersal phase. Thus, for many coral reef fishes their life history consists of 3 stages, each in a different habitat: larval (planktonic), juvenile (demersal), and adult (demersal).

*E-mail: aadams@mote.org
This 3-phase life cycle may serve to decouple adult reproduction from recruitment of new individuals into the local population, or to decouple settlement of larvae from population dynamics of local adult populations.

The extent to which nursery habitats influence fish assemblages on coral reefs is unclear, because of the uncertainty as to whether reef fish assemblages are more influenced by larval supply and settlement processes, which involve the larval phase and the settlement transition, as opposed to post-settlement processes, which involve juvenile and adult phases and the juvenile-adult habitat transition (reviewed in Jones 1991). One school of thought proposes that larval supply and settlement is the primary factor influencing 
fish abundance, i.e. reef fish populations do not reach resource-defined carrying capacities because larval supply is insufficient (e.g. Doherty 1982, 1983, Sale et al. 1984, Victor 1983, 1986, Abrams 1984, Fowler et al. 1992, Doherty \& Fowler 1994, Sale 1982).

Contrary to the larval supply limitation model, other investigators (review in Jones 1991) argue that postsettlement processes are more influential in determining reef fish abundance. Factors that may influence fish abundance include the amount, type, and distribution of habitat (Ebersole 1985, Eggleston 1995, Tolimieri 1995, Tupper \& Boutilier 1997), predation (Hixon \& Beets 1989, 1993, 1997, Hixon 1991, Beukers \& Jones 1997, Eggleston et al. 1997, Steele 1997a), competition (Smith \& Tyler 1972), disturbance (Bohnsack \& Talbot 1980), or a combination of factors (Shulman et al. 1983, Shulman 1985a, Shulman \& Ogden 1987, Steele $1997 b)$. Moreover, the ability of settlement- and postsettlement-stage fishes to select among habitats (Frederick 1997, Levin et al. 1997a, McCormick \& Makey 1997, Risk 1997, Stobutzki \& Bellwood 1997) indicates that finding a suitable nursery habitat is worth the energy and predation risk associated with exploratory movement. Finally, there is an emerging view that the importance of larval supply and settlement to reef fish populations may vary, depending upon the vagility and site-attachment of different species (Ault \& Johnson 1998), the degree of isolation versus continuity of habitat in different reef systems (Ault \& Johnson 1998), geographic differences in larval supply (Levin et al. 1997b, Tolimieri et al. 1998, Casselle 1999), and postsettlement influences on fishes (Green 1996, Sponaugle \& Cowen 1996). While much is known about microhabitat requirements for recruits and for adults of many coral reef fishes (Sale et al. 1984, Robertson 1988, Tolimieri 1998b) and post-settlement modification of recruitment patterns (Eggleston 1995, Tolimieri 1998a), the examination of the importance of off-reef habitats to ontogenetic development has just begun (Nagelkerken et al. 2000).

This paper reports findings from a study of putative nursery habitats of back-reef and lagoon areas of bank-barrier reefs on St. Croix, US Virgin Islands. Based upon findings from a pilot study, we expected that lagoonal patch-reef and rubble would be a preferred nursery habitat for coral reef fishes. Therefore, we investigated which post-settlement life stages of which species are associated with which lagoon habitats, the extent to which reef-associated species use the lagoon habitats as nurseries, and how the utilization of lagoon habitats by fishes differs from the use of back-reef habitats, in order to test the null hypothesis $\left(H_{0}\right)$ that there are no differences in densities of early post-settlement fishes among back-reef and lagoon habitats.

\section{METHODS}

Study location. Six study sites on the eastern end of St. Croix (Fig. 1), each comprising a section of backreef and its associated lagoon, are similar in terms of bank-barrier reef orientation and size, lagoon area, and habitat types. Seagrass beds, in which coral rubble, patch-reef, algal plain, and sand bottom habitats are patchily distributed, make up the habitat of the study lagoons, which are bounded on the seaward side by the back-reef of a bank-barrier reef. Wide, continuous, shallow $(<1 \mathrm{~m})$ reef crests prevent work on the reef platform and restrict access to the shallow forereef in all but the calmest weather, so these areas were not included in censusing. The back-reef is a shallow area composed mostly of highly inter-mixed calcareous pavement, patch-reef (coral heads) and rubble, with smaller patches of algal plain, sand, or seagrass mixed in. In contrast to the lagoon, potential nursery habitats of the back-reef are contiguous with the rest of the bank-barrier reef. Isolated sections of bank-barrier reef and associated lagoons were chosen for study sites to reduce movement of fishes that might occur between contiguous sections of reef or between lagoonal nurseries and non-adjacent sections of a contiguous reef tract, since considerable movement of young fishes may occur along a continuous reef tract but not among isolated sections of reef (Ault \& Johnson 1998).

Lagoon habitat types. We divided the lagoon habitats into 5 primary types: patch-reef, rubble, seagrass, algal plain, and sand. Each habitat type is identified based on the following characteristics. Patch-reef: isolated, high-relief, calcareous structure (not part of the contiguous reef), with a vertical profile that often, but not always, contains live coral cover, the most important characteristic is vertical relief. Rubble: lowrelief, calcareous structure composed primarily of conch shells or dead/dying coral fragments that are not attached to the substrate; rubble habitat may occur over extended areas or as isolated fragments within seagrass, sand, or algal plain habitats. Seagrass: monospecific, or nearly monospecific, stands of Thalassia testudinum, with varying densities of Syringodium filiforme mixed in. Algal plain: areas of open sand with no or very little ( $<10 \%$ cover) plants or coralline material represented. Sand: sand bottom dominated by Halimeda spp., Penicillus spp., and Udotea spp., which may include sparse stands of $T$. testudinum and $S$. filiforme.

Field methods. Each of the 6 study sites was censused on 2 non-consecutive days during 2 wk census periods in June and October 1999 and February 2000. To ensure consistency of counts, the same 2 observers conducted all transects. The lagoon and bank-barrier back-reef areas were censused separately within 


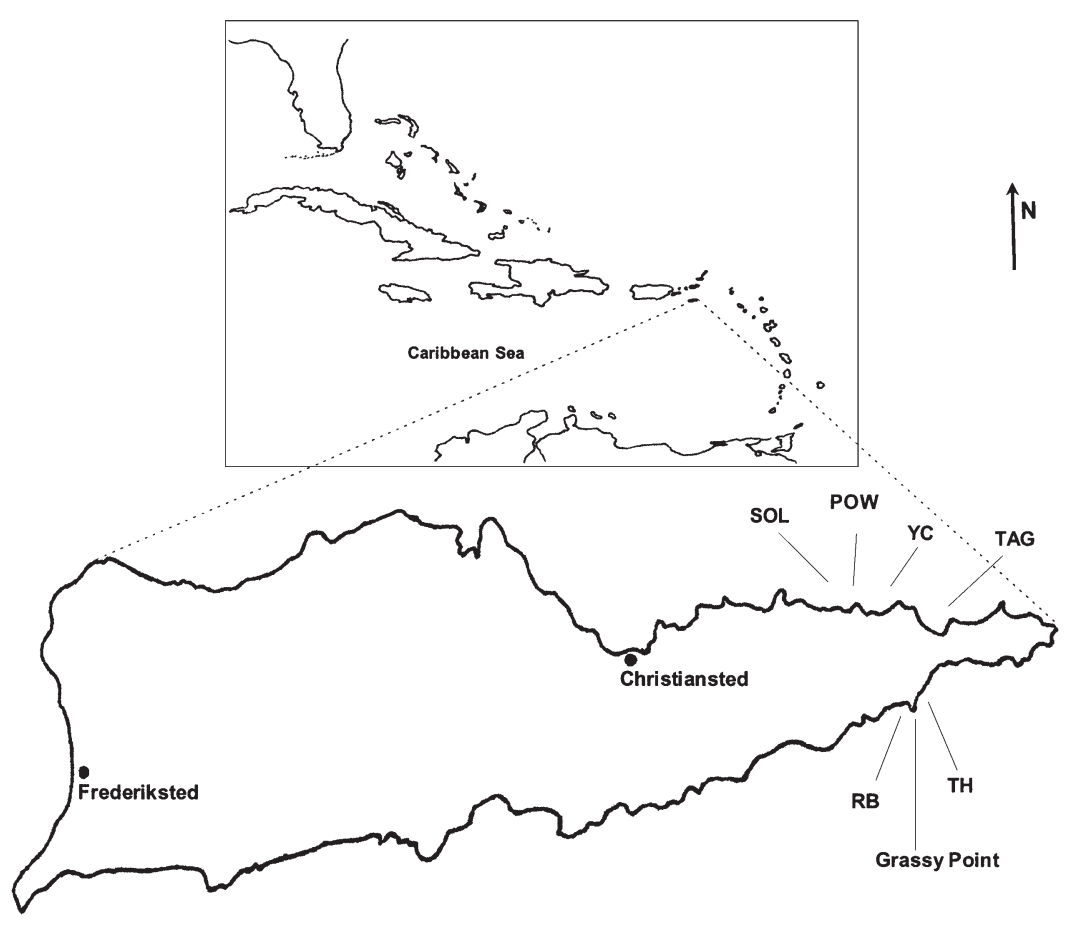

Fig. 1. Locations of study sites at the eastern end of St. Croix. RB: Rod Bay, TH: Turner Hole, TAG: Tague Bay, YC: Yellowcliff Bay, POW: Pow Point, SOL: Solitude Bay

each day for each site. All non-cryptic fishes (i.e. all except cryptic species such as gobiids, apogonids, and bleniids) within a $50 \mathrm{~m}$ long $\times 2 \mathrm{~m}$ wide $\times 2 \mathrm{~m}$ high transect were counted, and recorded in size categories $(<3 \mathrm{~cm}, 3$ to $5 \mathrm{~cm},>5 \mathrm{~cm})$. Size categories were used to reduce potential differences in the estimation of fish size by the 2 observers over the course of the study. Furthermore, the clipboards which held the census data sheets were marked with size increments for in situ size reference. Within lagoons, the location and direction of transects were randomized, and fishes were recorded in association with a given habitat. The length of transect tape crossing each habitat type was noted to provide estimates of percent cover by habitat type and to allow calculations of fish densities for each habitat type. Back-reef transects were parallel to the longitudinal axis of the back-reef, with no differentiation of habitat types because of the highly inter-mixed nature of the backreef habitats. On each census day, 14 back-reef transects and 20 lagoon transects were completed for 1 of the 6 sites. The basic unit of analysis was the census data collected from a single site in a single day. Thus, for each census period, for each study site, there were 2 census days, each with a total of $1400 \mathrm{~m}^{2}$ of backreef habitats and $2000 \mathrm{~m}^{2}$ of lagoon habitats censused.
Analysis. Densities of 4 focal 'species' and of all fishes combined were examined to determine which lagoon habitats were most heavily used. The 4 focal species (or nominal species) Acanthurus spp., Haemulon spp., Sparisoma aurofrenatum, and Scarus iserti were selected based on frequency of occurrence and overall abundance on back-reefs and lagoon habitats (to ensure sufficient data for analysis), economic importance (e.g. pomadasyids are important in the commercial fishery), trophic importance (e.g. acanthurids and scarids are important grazers on coral reefs), and species of particular concern (e.g. scarids are under increased fishing pressure and have declined in abundance on St. Croix and other Caribbean islands). Since newly settled individuals of Acanthurus spp. (A. bahianus and A. chirurgus) and Haemulon spp. (H. aurolineatum, $H$. carbonarium, H. chrysargyreum, $H$. flavolineatum, $H$. macrostomum, $H$. plumieri, and $H$. sciurus) are difficult to identify at the species level, we pooled the species within each genus to form 2 nominal species for data analysis.

Several studies have demonstrated the importance of ontogenetic shifts for many coral reef fishes (Shulman 1985b, Eggleston 1995, Nagelkerken et al. 2000). To provide new information, we focus on quantifying how each size class of different coral reef fishes utilizes available habitats, examining each size class and thus each life stage as a separate biological entity. To compare utilization among the back-reef habitat and the various lagoon habitats, and so determine whether lagoon habitats thought to be nurseries actually attract more settlers and sustain more juveniles than the back-reef, we applied repeatedmeasures ANOVA to densities of the 3 different size classes for the 4 focal species and for all species combined. Density data were $\log (x+1)$-transformed prior to analyses, and we used the Huynh-Feldt adjusted probability if the model did not meet the sphericity assumption (Wilkinson et al. 1996). Although the data distributions remained positively skewed after transformation, repeated-measures ANOVA was used because (1) we censused fish assemblages at the same sites repeatedly over time so the measurements might not have been independent, and (2) these distributions lead to conservative Type-I errors in ANOVA (Glass et al. 1972). One or more lagoon 

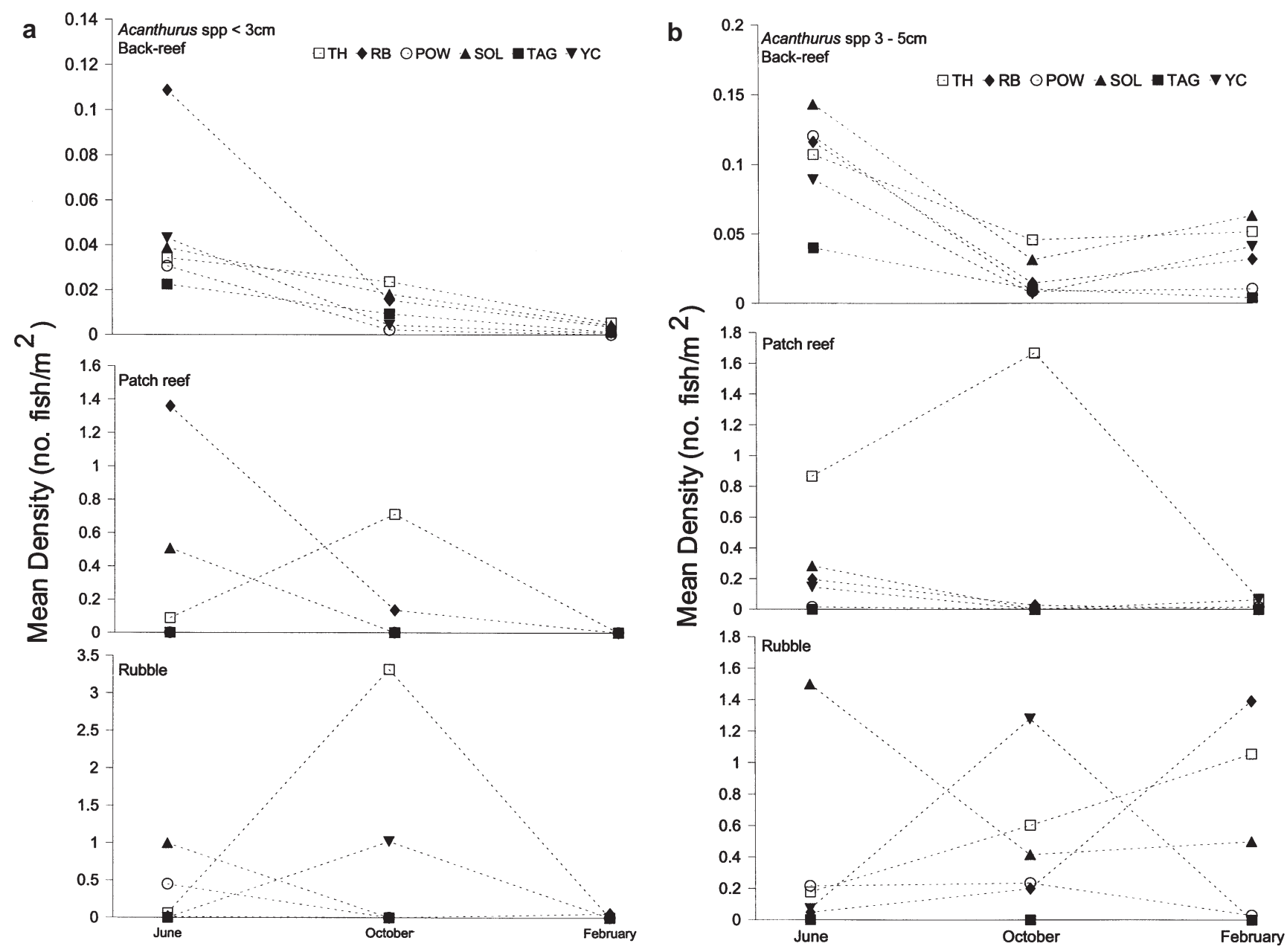

Fig. 2. (Above and facing page.) Acanthurus spp. Mean ( $\mathrm{n}=2$ for each season $\times$ site $\times$ habitat) density of by season, habitat (backreef, patch-reef, rubble) and site. (a) Small $(<3 \mathrm{~cm})$ fishes, (b) medium $(3$ to $5 \mathrm{~cm})$ fishes, (c) large $(>5 \mathrm{~cm})$ fishes. Note that $y$-axis scale differs among graphs

habitats were not encountered on a census day in some months for some sites, resulting in empty cells in the data matrix (12 missing of 648 total cells). Six of the missing cells were for the patch-reef habitat, 4 cells for the rubble habitat, 1 cell for the seagrass habitat, and 1 cell for the sand habitat. Since the loss of cells from the site-habitat matrix sometimes resulted in multicolinearity because of too few values for a habitat-site interaction term, we replaced each missing cell with the average for the corresponding habitat (pooled across all sites) for that month. This provided a conservative estimate of the missing value. Analyses and results were examined for possible impacts of this data procedure, and in no case was there a detectable influence. For the 4 focal species, habitats were excluded from analyses if the species was either absent or rare (i.e. present on less than $5 \%$ of census dates) in that habitat.

\section{RESULTS}

A total of 176024 fishes were recorded over the 3 census periods, representing 97 species (Appendix 1). On the back-reef, 92 species were recorded and in the lagoon 78 species. Within the lagoon, 72 species were recorded on the patch-reef, 39 species on rubble, 25 species on seagrass, 26 species on the algal plain, and 11 species on sand. The mean estimated percent cover of lagoon habitat types varied by site, but rankings were similar among sites, with seagrass and algal plain most abundant, and patch-reef and rubble covering the least area of the bottom. The 4 focal 'species' accounted for $36.9 \%$ of all fishes counted. In the small $(<3 \mathrm{~cm})$ size class, Acanthurus spp. accounted for 3.3\%, Haemulon spp. for $54.2 \%$, Sparisoma aurofrenatum for $3.2 \%$, and Scarus iserti for $14.7 \%$ of all fishes counted. In the medium (3 to $5 \mathrm{~cm}$ ) size class, Acanthurus spp. 


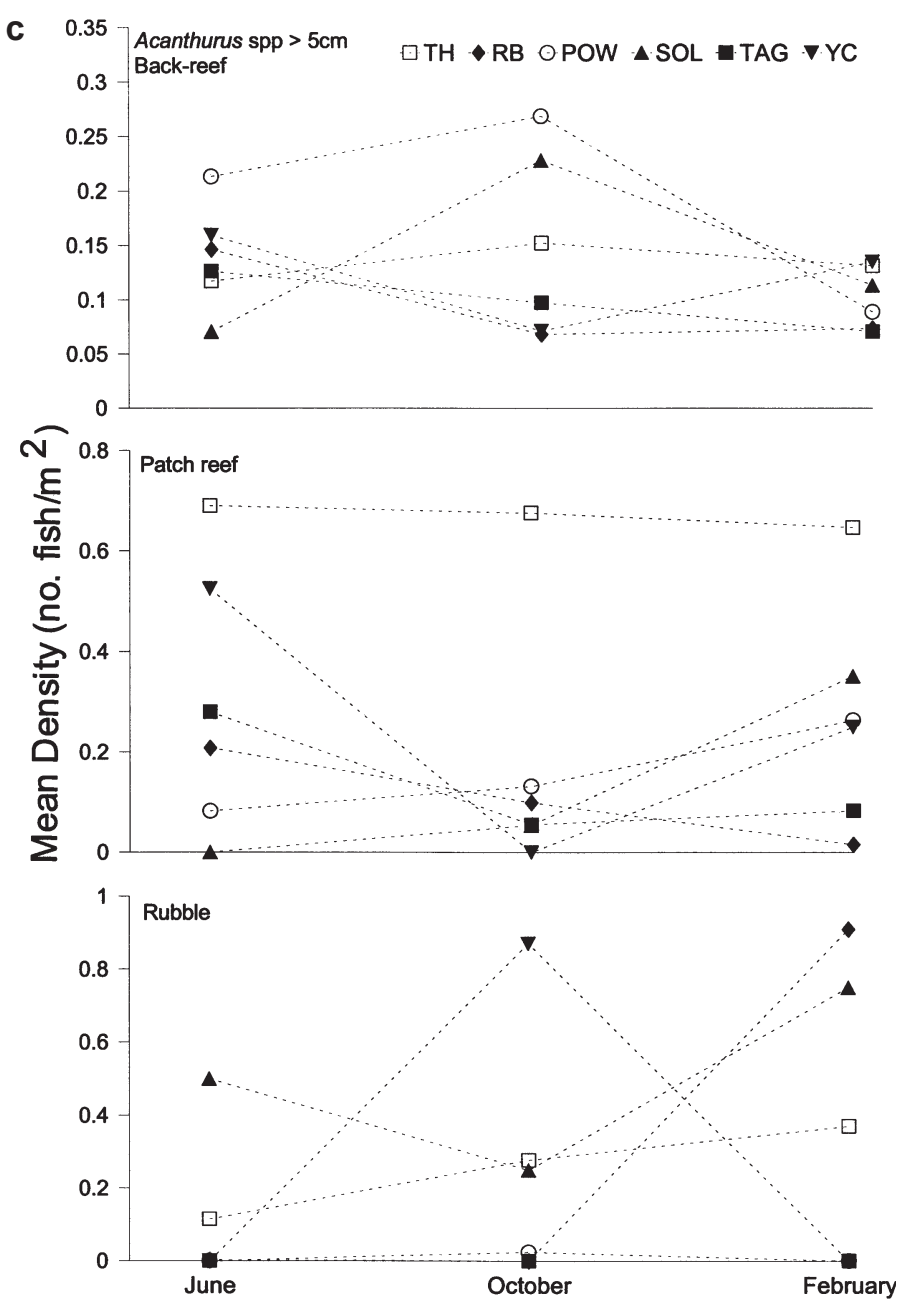

Fig. 2 (continued) accounted for $4.9 \%$, Haemulon spp. for $4.5 \%, S$. aurofrenatum for $2.9 \%$, and $S$. iserti for $12.7 \%$ of all fishes counted. In the large $(>5 \mathrm{~cm})$ size class, Acanthurus spp. accounted for $10.8 \%$, Haemulon spp. for $8.9 \%, S$. aurofrenatum for $2.9 \%$, and $S$. iserti for $8.7 \%$ of all fishes counted.

Most settlement of Acanthurus spp. occurred during spring and summer (Fig. 2a), with peak densities of small fishes in either June (3 sites) or October (2 sites). Timing of settlement varied among sites, but not among habitats within sites. Acanthurus spp. were either absent or rare in the seagrass and algal plain, and were never recorded in sand habitats; so these 3 habitats were excluded from the ANOVA for this taxon. Of the remaining habitats, small and medium Acanthurus spp. preferred lagoon patch-reef and rubble over back-reef. We often observed groups of small and medium Acanthurus spp. using seagrass bordering patch-reef and rubble. Upon our approach these individuals retreated to the shelter of the nearby patch-reef or rubble habitat, and were recorded as inhabiting the patch-reef or the rubble. The significant season $\times$ habitat $\times$ site interaction for small fishes and habitat $\times$ site interaction for medium fishes (Table 1 ) are not surprising given variation in timing of settlement and spatial variability of incoming larvae (Caselle \& Warner 1996). These interactions do not obscure the important finding that small and medium fishes prefer lagoon patch-reef and rubble over backreef. Tague Bay had few small or medium Acanthurus spp. At 4 of the 5 other sites, highest densities of small $(<3 \mathrm{~cm})$ Acanthurus spp. were found on rubble, and at the remaining site on patch-reef (Fig. 2a). The highest densities of medium ( 3 to $5 \mathrm{~cm}$ ) Acanthurus spp. were found on rubble at 3 sites and on patch-reef at 2 sites (Fig. 2b). Large (> 5cm) Acanthurus spp. showed the

Table 1. Acanthurus spp. Results of repeated-measures ANOVA of $\log (x+1)$-transformed density by size class. Categorical factors are habitat (only back-reef, patch-reef, and rubble are included: no fishes or insufficient fishes in other habitats) and site, repeated by season. ns: not significant $(\mathrm{p}>0.05){ }^{*} \mathrm{p}<0.05{ }_{i}{ }^{* *} \mathrm{p}<0.01{ }^{* * *} \mathrm{p}<0.005$

\begin{tabular}{|c|c|c|c|c|c|c|c|}
\hline \multirow{3}{*}{ Source } & \multirow[t]{3}{*}{$\mathrm{df}$} & & 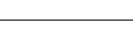 & \multirow{2}{*}{\multicolumn{2}{|c|}{$\begin{array}{l}\text { Size class } \\
3 \text { to } 5 \mathrm{~cm}\end{array}$}} & \multirow{2}{*}{\multicolumn{2}{|c|}{$>5 \mathrm{~cm}$}} \\
\hline & & \multicolumn{2}{|c|}{$<3 \mathrm{~cm}$} & & & & \\
\hline & & MS & $F$ & MS & $F$ & MS & $F$ \\
\hline \multicolumn{8}{|l|}{ Between factors } \\
\hline Habitat & 2 & 0.0370 & $6.499^{* *}$ & 0.1470 & $11.398^{* * *}$ & 0.0133 & $0.712^{\text {ns }}$ \\
\hline Site & 5 & 0.0214 & $3.761^{*}$ & 0.0570 & $4.422^{* *}$ & 0.0273 & $1.463^{\mathrm{ns}}$ \\
\hline Habitat $\times$ Site & 10 & 0.0141 & $2.474^{*}$ & 0.0313 & $2.426^{*}$ & 0.0290 & $1.554^{\mathrm{ns}}$ \\
\hline \multicolumn{8}{|l|}{ Within factors } \\
\hline Season & 2 & 0.0446 & $5.883^{* *}$ & 0.0003 & $0.013^{\mathrm{ns}}$ & 0.0135 & $0.564^{\mathrm{ns}}$ \\
\hline Season $\times$ Habitat & 4 & 0.0164 & $2.162^{\mathrm{ns}}$ & 0.0222 & $0.959^{\mathrm{ns}}$ & 0.0200 & $0.832^{\text {ns }}$ \\
\hline Season $\times$ Site & 10 & 0.0370 & $4.881^{* * *}$ & 0.0138 & $0.598^{\mathrm{ns}}$ & 0.0148 & $0.617^{\mathrm{ns}}$ \\
\hline Season $\times$ Habitat $\times$ Site & 20 & 0.0172 & $2.269^{*}$ & 0.0176 & $0.763^{\mathrm{ns}}$ & 0.0145 & $0.605^{\mathrm{ns}}$ \\
\hline
\end{tabular}


least variation in density over space and time (Fig. 2c). Although densities of large Acanthurus spp. were highest on the back-reef at some sites, this difference was not significant (Table 1). In contrast to small fish, the density of large Acanthurus spp. did not vary significantly over time; this segment of the population appears to be fairly stable in most habitats at most sites. It is important to note that the large size category includes juveniles (potentially in transition from postsettlement to adult habitats) and adults, so the nonsignificant finding for habitat use is not unexpected.

Small $(<3 \mathrm{~cm})$ Haemulon spp. were recorded on all habitats except sand. There was no significant difference among habitats in densities of small Haemulon spp. (Table 2), even though graphical examination of the data suggest that small Haemulon spp. prefer lagoonal patch-reef and rubble. We suggest that these differences are not significantly different because of the extremely patchy nature of Haemulon spp., and thus high variance in density estimates within habitats. Furthermore, we observed newly settled $(<1 \mathrm{~cm})$ Haemulon spp. most frequently in seagrass and algal plain habitats, and only infrequently in back-reef, patch-reef, and rubble, which is in agreement with previous studies (Shulman 1985a, Shulman \& Ogden 1987, Nagelkerken 2000). In contrast, medium (3 to $5 \mathrm{~cm})$ Haemulon spp. were not present on seagrass, algal plain, or sand, and showed no preference among back-reef, patch-reef, and rubble habitats. Large Haemulon spp. preferred back-reef over patch-reef and rubble, and were not present on other habitats (Table 2). This indicates a clear ontogenetic shift from plant-dominated habitats to calcium carbonate habitats. Only small Haemulon spp. showed a significant seasonal variation in density (Table 2), as occurred in Acanthurus spp. Settlement appears to be concentrated in summer, as densities of small individuals peaked in October at all sites.
In stark contrast to Acanthurus spp. and Haemulon spp., the significant differences in habitat densities of Sparisoma aurofrenatum were due to a distinct preference for back-reef and patch-reef over any other habitat for all size classes (Table 3, Fig. 3). S. aurofrenatum were absent or extremely rare in seagrass, algal plain, and sand habitats, and were rare on rubble: almost all the $S$. aurofrenatum of all size classes recorded on rubble were at 1 site, Yellowcliff Bay (Fig. 3). Small $S$. aurofrenatum that were just beginning to gain color were seen, alone or in groups of 3 or fewer, hiding among algae, but only in back-reef and patch-reef habitats. Since all size classes showed similar habitat utilization patterns, it is apparent that there is little, if any, ontogenetic habitat shift in this parrotfish. In contrast again with Acanthurus spp. and Haemulon spp., no clear settlement pulse emerged for $S$. aurofrenatum (Fig. 3a). The highly significant seasonal differences for small $(<3 \mathrm{~cm}) S$. aurofrenatum cannot be interpreted due to complex, and equally strong, season $\times$ habitat $x$ site interactions (Table 3 ). Although season $x$ habitat interactions for medium (3 to $5 \mathrm{~cm}$ ) and large $(>5 \mathrm{~cm})$ S. aurofrenatum densities were significant (Table 3), no clear trend was evident for either size class (Fig. 3b,c), although the preference for back-reef habitat was consistent for both size classes.

Like Sparisoma aurofrenatum, Scarus iserti showed a strong preference for complex, high-relief structure, with no ontogenetic shift in habitat. $S$. iserti were extremely rare (i.e. incidental) on rubble, seagrass, algal plain, and sand, and showed no preference between back-reef and patch-reef habitats (Table 4). Higher densities of small $(<3 \mathrm{~cm}) S$. iserti in June and October indicate that settlement occurs mostly in summer (Table 4), although some settlers were seen on the back-reef in February. The significant season $\times$ site interaction for medium (3 to $5 \mathrm{~cm}$ ) $S$. iserti was due to high densities at Tague Bay (Table 4). Tague Bay also

Table 2. Haemulon spp. Results of repeated-measures ANOVA of log $(x+1)$-transformed density of by size class. Categorical factors are habitat (only back-reef, patch-reef, rubble, seagrass, and algal plain are included: no fishes on sand) and site, repeated by season. ns: not significant $(\mathrm{p}>0.05){ }_{i}^{* * *} \mathrm{p}<0.005$

\begin{tabular}{|c|c|c|c|c|c|c|c|}
\hline \multirow{3}{*}{ Source } & \multirow{3}{*}{ df } & \multirow{2}{*}{\multicolumn{2}{|c|}{$<3 \mathrm{~cm}$}} & \multirow{2}{*}{\multicolumn{2}{|c|}{$\begin{array}{l}\text { Size class } \\
3 \text { to } 5 \mathrm{~cm}\end{array}$}} & \multirow{2}{*}{\multicolumn{2}{|c|}{$>5 \mathrm{~cm}$}} \\
\hline & & & & & & & \\
\hline & & MS & $F$ & MS & $F$ & MS & $F$ \\
\hline \multicolumn{8}{|l|}{ Between factors } \\
\hline Habitat & 4 & 0.0266 & $2.198^{\mathrm{ns}}$ & 0.0066 & $1.357^{\mathrm{ns}}$ & 0.0103 & $7.446^{* * *}$ \\
\hline Site & 5 & 0.0145 & $1.196^{\mathrm{ns}}$ & 0.0042 & $0.871^{\mathrm{ns}}$ & 0.0015 & $1.094^{\mathrm{ns}}$ \\
\hline Habitat $\times$ Site & 20 & 0.0087 & $0.719^{\text {ns }}$ & 0.0051 & $1.058^{\mathrm{ns}}$ & 0.0013 & $0.956^{\mathrm{ns}}$ \\
\hline \multicolumn{8}{|l|}{ Within factors } \\
\hline Season & 2 & 0.0991 & $8.313^{* * *}$ & 0.0035 & $0.732^{\text {ns }}$ & 0.0003 & $0.170^{\mathrm{ns}}$ \\
\hline Season $\times$ Habitat & 8 & 0.0199 & $1.671^{\mathrm{ns}}$ & 0.0121 & $2.527^{\mathrm{ns}}$ & 0.0009 & $0.640^{\mathrm{ns}}$ \\
\hline Season $\times$ Site & 10 & 0.0095 & $0.799^{\text {ns }}$ & 0.0057 & $1.194^{\mathrm{ns}}$ & 0.0016 & $1.125^{\mathrm{ns}}$ \\
\hline Season $\times$ Habitat $\times$ Site & 40 & 0.0138 & $1.161^{\mathrm{ns}}$ & 0.0077 & $1.608^{\mathrm{ns}}$ & 0.0025 & $1.738^{\mathrm{ns}}$ \\
\hline
\end{tabular}


Table 3. Sparisoma aurofrenatum. Results of repeated measures ANOVA of $\log (x+1)$-transformed density by size class. Categorical factors are habitat (only back-reef, patch-reef, and rubble are included: no fishes on other habitats) and site, repeated by season. ns: not significant $(\mathrm{p}>0.05) ;{ }^{*} \mathrm{p}<0.05 ;{ }^{* *} \mathrm{p}<0.01 ;{ }^{* * *} \mathrm{p}<0.005$

\begin{tabular}{|c|c|c|c|c|c|c|c|}
\hline \multirow{3}{*}{ Source } & \multirow{3}{*}{ df } & & & \multirow{2}{*}{\multicolumn{2}{|c|}{$\begin{array}{c}\text { - Size class } \\
3 \text { to } 5 \mathrm{~cm}\end{array}$}} & & \\
\hline & & \multicolumn{2}{|c|}{$<3 \mathrm{~cm}$} & & & \multicolumn{2}{|c|}{$>5 \mathrm{~cm}$} \\
\hline & & MS & $F$ & \multicolumn{2}{|c|}{ MS } & MS & $F$ \\
\hline \multicolumn{8}{|l|}{ Between factors } \\
\hline Habitat & 2 & 0.0008 & $18.564^{* * *}$ & 0.0020 & $5.192^{*}$ & 0.0020 & $30.098^{* * *}$ \\
\hline Site & 5 & 0.0002 & $5.189^{* *}$ & 0.0002 & $0.631^{\mathrm{ns}}$ & 0.0010 & $15.545^{* * *}$ \\
\hline Habitat $\times$ Site & 10 & 0.0001 & $3.282^{*}$ & 0.0004 & $1.039^{\mathrm{ns}}$ & 0.0001 & $1.413^{\mathrm{ns}}$ \\
\hline \multicolumn{8}{|l|}{ Within factors } \\
\hline Season & 2 & 0.0006 & $15.772^{* * *}$ & 0.0004 & $1.257^{\mathrm{ns}}$ & 0.0003 & $2.490^{\mathrm{ns}}$ \\
\hline Season $\times$ Habitat & 4 & 0.00003 & $0.740^{\mathrm{ns}}$ & 0.0012 & $3.821^{*}$ & 0.0006 & $4.754^{* * *}$ \\
\hline Season $\times$ Site & 10 & 0.0002 & $5.528^{* * *}$ & 0.0004 & $1.371^{\mathrm{ns}}$ & 0.0001 & $1.073^{\mathrm{ns}}$ \\
\hline Season $\times$ Habitat $\times$ Site & 20 & 0.00001 & $2.918^{* * *}$ & 0.0003 & $1.009^{\mathrm{ns}}$ & 0.0001 & $1.109^{\mathrm{ns}}$ \\
\hline
\end{tabular}

Table 4. Scarus iserti. Results of repeated measures ANOVA of $\log (x+1)$-transformed density of by size class. Categorical factors are habitat (only back-reef and patch-reef, no fish on other habitats) and site, repeated by season. ns: not significant ( $p>0.05$ ); ${ }^{*} \mathrm{p}<0.05 ;{ }^{* *} \mathrm{p}<0.01 ;{ }^{* * *} \mathrm{p}<0.005$

\begin{tabular}{|c|c|c|c|c|c|c|c|}
\hline \multirow[t]{3}{*}{ Source } & \multirow{3}{*}{ df } & & & \multicolumn{2}{|c|}{ Size class } & \multirow{2}{*}{\multicolumn{2}{|c|}{$>5 \mathrm{~cm}$}} \\
\hline & & \multicolumn{2}{|c|}{$<3 \mathrm{~cm}$} & \multicolumn{2}{|c|}{3 to $5 \mathrm{~cm}$} & & \\
\hline & & MS & $F$ & MS & F & MS & $F$ \\
\hline \multicolumn{8}{|l|}{ Between factors } \\
\hline Habitat & 1 & 0.0112 & $3.835^{\mathrm{ns}}$ & 0.0010 & $1.060^{\mathrm{ns}}$ & 0.0010 & $2.031^{\mathrm{ns}}$ \\
\hline Site & 5 & 0.0161 & $5.514^{* *}$ & 0.0333 & $34.015^{* * *}$ & 0.0088 & $18.470^{* * *}$ \\
\hline Habitat $\times$ Site & 10 & 0.0033 & $1.128^{\mathrm{ns}}$ & 0.0016 & $1.597^{\mathrm{ns}}$ & 0.0027 & $5.616^{* *}$ \\
\hline \multicolumn{8}{|l|}{ Within factors } \\
\hline Season & 2 & 0.0061 & $5.253^{*}$ & 0.0202 & $7.133^{* * *}$ & 0.0074 & $4.016^{*}$ \\
\hline Season $\times$ Habitat & 4 & 0.0008 & $0.725^{\mathrm{ns}}$ & 0.0017 & $0.596^{\mathrm{ns}}$ & 0.0011 & $0.613^{\mathrm{ns}}$ \\
\hline Season $\times$ Site & 10 & 0.0018 & $1.579^{\mathrm{ns}}$ & 0.0080 & $2.824^{*}$ & 0.0017 & $0.928^{\mathrm{ns}}$ \\
\hline Season $\times$ Habitat $\times$ Site & 20 & 0.0008 & $0.670^{\mathrm{ns}}$ & 0.0039 & $1.371^{\mathrm{ns}}$ & 0.0011 & $0.568^{\mathrm{ns}}$ \\
\hline
\end{tabular}

appears to be influential in the significant season effect for large $(>5 \mathrm{~cm}) S$. iserti (Table 4$)$. We observed $S$. iserti of all size classes on the back-reef and some large lagoon patch-reefs moving about the reef in roving schools, usually segregated by size, of a few to tens of individuals, and frequently stopping to feed. Larger individuals $(>10 \mathrm{~cm}$ ) were usually observed as singles or pairs rather than traveling with roving schools.

Spatial and temporal patterns of habitat use can be discerned for all species combined, despite a significant season $\times$ habitat interaction (Table 5). The general trend of community level utilization of lagoonal nursery habitats is important in that this suggests that the findings for Acanthurus spp. and Haemulon spp. may be applicable to other species. Lagoon patch-reef and rubble were generally the most heavily used habitats, especially by small $(<3 \mathrm{~cm})$ and medium $(3$ to $5 \mathrm{~cm}$ ) fishes in spring and summer. Of the 92 species recorded on back-reefs, 33 also utilized the lagoon patch-reef and 22 used rubble when they were small $(<3 \mathrm{~cm})$, and 42 were also found on patch-reef and 23 on rubble at medium size (Appendix 1). In contrast, 65 species used lagoon patch-reef and 29 rubble when large $(>5 \mathrm{~cm})$. Seagrass, algal plain, and sand habitats contained low densities of fishes in all size classes, with the exception of recently settled Haemulon spp. in seagrass. Most settlement occurred during summer, as indicated by high densities of small $(<3 \mathrm{~cm})$ and medium ( 3 to $5 \mathrm{~cm}$ ) fishes during the June and October census periods. Within lagoon habitats, the month of highest density of small fishes on patch-reefs varied, with small-fish density highest in June at 3 sites, and greatest in October at 2 sites. Within the rubble habitat, small-fish densities were highest in October at 5 of 6 study sites. By February, the densities of small and medium fishes were low. The density of large fishes (>5 cm) remained relatively stable over time.

\section{DISCUSSION}

We discerned 2 patterns of habitat use among coral reef fishes on St. Croix: one group of fishes use lagoon patch-reef and rubble habitats as nurseries, while the 

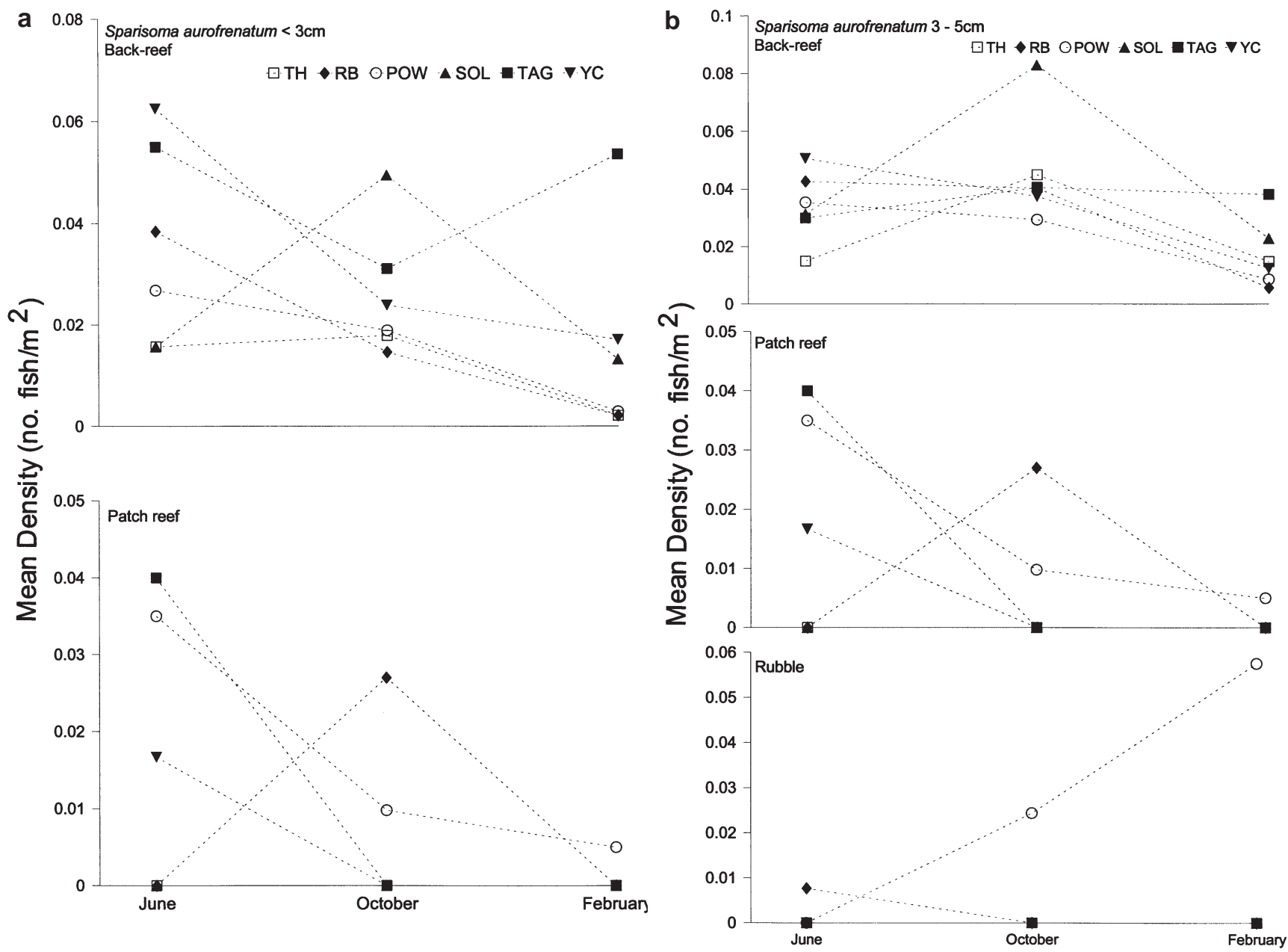

Fig. 3. (Above and facing page.) Sparisoma aurofrenatum. Mean ( $\mathrm{n}=2$ for each season $\times$ site $\times$ habitat) density of by season, habitat (back-reef, patch-reef, rubble) and site. (a) Small $(<3 \mathrm{~cm})$ fishes, (b) medium $(3$ to $5 \mathrm{~cm})$ fishes, $(\mathrm{c})$ large $(>5 \mathrm{~cm})$ fishes. Note that $y$-axis scale differs among graphs

Table 5. All species combined. Results of repeated-measures ANOVA of $\log (x+1)$-transformed density by size class. Categorical factors are habitat (back-reef, patch-reef, rubble, seagrass, algal plain, and sand) and site, repeated by season. ns: not significant $(\mathrm{p}>0.05) ;{ }^{*} \mathrm{p}<0.05{ }^{* *} \mathrm{p}<0.01 ;{ }^{* * *} \mathrm{p}<0.005$

\begin{tabular}{|c|c|c|c|c|c|c|c|}
\hline \multirow{3}{*}{ Source } & \multirow{3}{*}{$\mathrm{df}$} & & & \multirow{2}{*}{\multicolumn{2}{|c|}{$\begin{array}{c}\text { - Size class } \\
3 \text { to } 5 \mathrm{~cm}\end{array}$}} & & \\
\hline & & \multicolumn{2}{|c|}{$<3 \mathrm{~cm}$} & & & \multicolumn{2}{|c|}{$>5 \mathrm{~cm}$} \\
\hline & & MS & $F$ & \multicolumn{2}{|c|}{ MS $\quad F$} & MS & $F$ \\
\hline \multicolumn{8}{|l|}{ Between factors } \\
\hline Habitat & 5 & 0.8216 & $75.067^{* * *}$ & 1.8067 & $204.37^{* * *}$ & 2.008 & $112.72^{* * *}$ \\
\hline Site & 5 & 0.0888 & $8.112^{* * *}$ & 0.0508 & $5.754^{* * *}$ & 0.037 & $2.055^{\mathrm{ns}}$ \\
\hline Habitat $\times$ Site & 25 & 0.0175 & $1.601^{\mathrm{ns}}$ & 0.0358 & $4.052^{* * *}$ & 0.040 & $2.266^{*}$ \\
\hline \multicolumn{8}{|l|}{ Within factors } \\
\hline Season & 2 & 0.8540 & $55.365^{* * *}$ & 0.2086 & $15.589^{* * *}$ & 0.343 & $11.619^{* * *}$ \\
\hline Season $\times$ Habitat & 10 & 0.1782 & $11.553^{* * *}$ & 0.1112 & $8.307^{* * *}$ & 0.220 & $7.444^{* * *}$ \\
\hline Season $\times$ Site & 10 & 0.0410 & $2.659^{* *}$ & 0.0261 & $1.951^{\mathrm{ns}}$ & 0.012 & $0.416^{\mathrm{ns}}$ \\
\hline Season $\times$ Habitat $\times$ Site & 50 & 0.0181 & $1.173^{\mathrm{ns}}$ & 0.0152 & $1.137^{\mathrm{ns}}$ & 0.011 & $0.356^{\mathrm{ns}}$ \\
\hline
\end{tabular}




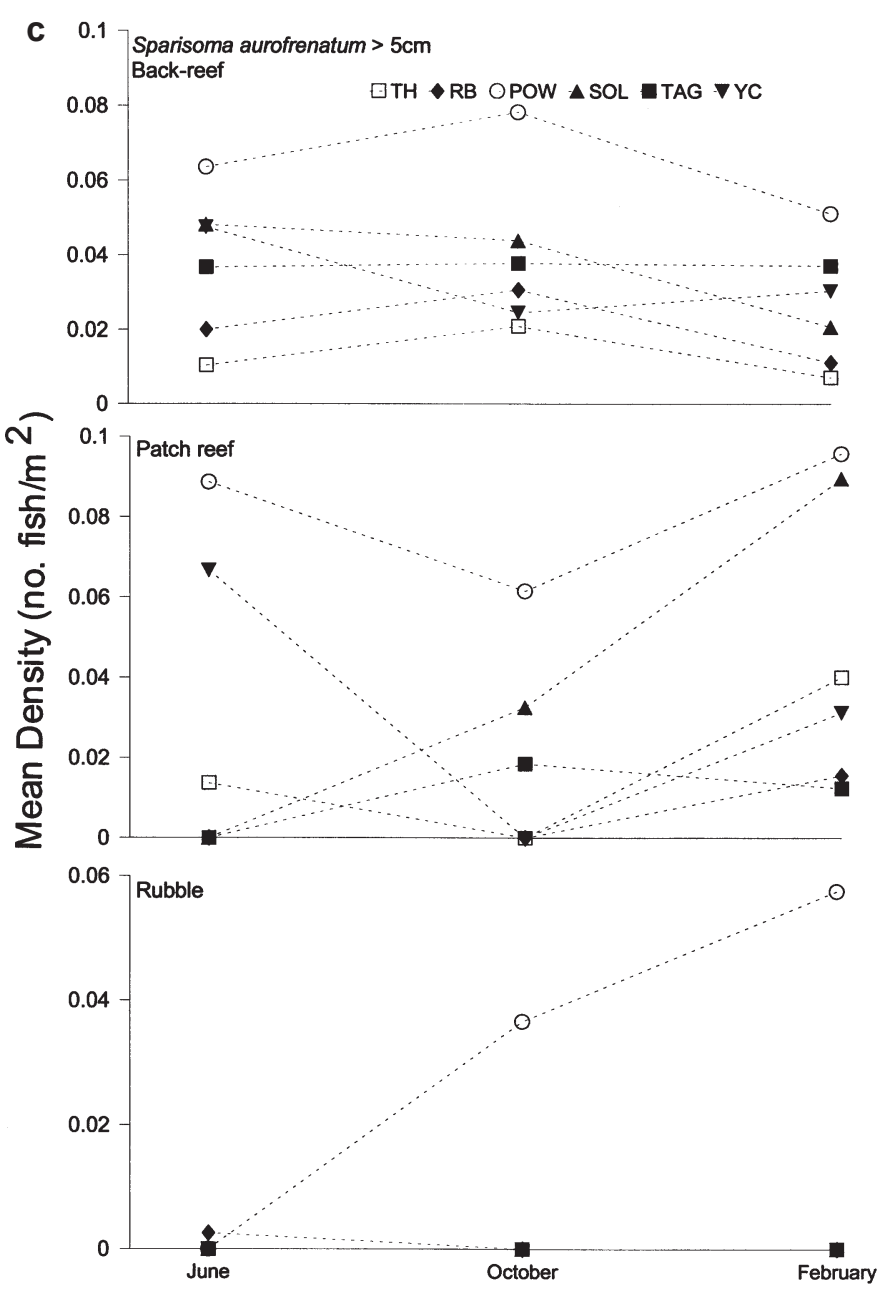

Fig. 3 (continued)

second group prefer the back-reef as nursery habitats. Small and medium (recent post-settlement and juvenile) fishes of species that utilize lagoons as nurseries, exemplified by Acanthurus spp. and Haemulon spp., prefer patch-reef and rubble habitats as nurseries over back-reef and other lagoon habitats (seagrass, algae, and sand-which cover a considerably larger area). Other species, exemplified by Scartus iserti and Sparisoma aurofrenatum, use lagoon habitats rarely, and use the back-reef as settlement, nursery, and adult habitat.

Competent Acanthurus spp. larvae can swim long distances (Sancho et al. 1997, Stobutzki \& Bellwood 1997) and delay metamorphosis for long periods, so they can explore potential settlement sites (McCormick 1999). Moreover, post-settlement A. bahianus and $A$. chirurgus may use a variety of habitat types (Robertson 1988, Mahon \& Mahon 1994, Risk 1997, Lawson et al. 1999, this study), so they can take advantage of the post-settlement transition period (Kaufman et al. 1992) to find the most suitable habitat for final settlement. Haemulids also show plasticity in settlement and post-settlement habitat use, with most settlement occurring in lagoon seagrass and algal plain, and post-settlement migration to patch-reef, rubble, or the back-reef habitat (Shulman \& Ogden 1987, this study). Pre-settlement larvae of fishes that use lagoon habitats as nurseries must pass over the bank-barrier reef and into the lagoon before finding patch-reef or rubble, indicating that these lagoon habitats must provide advantages that make it worth the energy and risk associated with the search.

Based upon the results of this study and results of other studies, we theorize that the general tendency of many species to use lagoon habitats as nurseries (Nagelkerken et al. 2000) may be explained by several factors.

First, recruitment declines as a resident population increases, so a location may become saturated (Shulman et al. 1983, Forrester 1995, 1999, Schmitt \& Holbrook 1999). In accordance with Munro et al. (1973) and Shulman (1985a), we found that settlement occurred mainly in summer, with only a small amount of settlement on the back-reef in winter. Suitable juvenile habitats on the back-reef may become saturated early during the summer, so that later-arriving fishes settle on lagoon habitats that are not yet saturated. In this scenario, lagoon patch-reef and rubble may attract more settlers in spring and summer because resources (food, shelter, and space) are more available than on the back-reef, which is crowded with fish of all ages competing for these resources. In winter, when the density of fishes is lowest, incoming larvae may settle on the first appropriate habitat they encounter - which is the back-reef.

Second, differences among habitats in the density of post-settlement fishes may reflect differences in predation rates, regardless of initial settlement patterns. Examples abound: Risk (1997) found that, although initial settlement of Acanthurus bahianus is higher on the back-reef than the reef crest or fore-reef, persistence is lower on the back-reef; predation on juveniles on small patch-reefs is higher on patch-reefs near the back-reef than on those that are farther away (Shulman 1985b); juvenile acanthurids on large lagoonal patch-reefs suffer greater predation at the patch-reef edges (Sweatman \& Robertson 1994); and predation of tethered juvenile $A$. chirurgus was lower in tidepools than in nearby reef habitats in Costa Rica (A.J.A. unpubl. data). Within lagoons, structurally complex patch-reef and rubble provide protection from predation (reviewed in Hixon 1991). Moreover, patch-reefs and rubble are located within seagrass, algal plain, or sand habitats, so post-settlement fishes that occupy patchreef and rubble have access to food sources in the sur- 
rounding habitats. Since food availability may be as important as shelter (Kerrigan 1994), especially for species that suffer size-dependent mortality (Levin et al. 1997a), patch-reef and rubble surrounded by habitats that provide adequate food should be highly attractive to post-settlement and juvenile fishes (Shulman 1985b).

Third, interspecific priority effects may influence the distribution of post-settlement fishes. For example, the territorial pomacentrid Stegastes leucostictus tends to reduce settlement and post-settlement persistence of Acanthurus spp. (Shulman et al. 1983, Risk 1998), and settlement of Haemulon spp. is reduced by the presence of juvenile predators, such as lutjanids, that settled earlier (Shulman et al. 1983). Haemulid recruitment to a marine reserve in Barbados, with many predators, was lower than to an adjacent unprotected area with fewer predators (Tupper \& Juanes 1999), and predation of post-settlement fishes is higher on artificial reefs with holes large enough to support resident predators than on reefs without large holes (Hixon \& Beets 1993, Beets 1997).

Patch-reef and rubble may offer different advantages as nursery habitat. Predation may be especially low on rubble, which, unlike patch-reefs, does not have holes large enough for predatory fishes. In contrast, patch-reefs may offer more shelter and more conspicuous targets for incoming larvae or 'bouncing' post-larvae (individuals in the post-settlement transition; Kaufman et al. 1992), since they cover a greater area of bottom, have more vertical relief, and have a more complex structure. The density of small fishes on patch-reefs peaked in June for 3 of the 6 study sites, but peaked on rubble in October for 5 of the 6 sites, suggesting a preference for patch-reef over rubble. However, much more research is needed to determine whether fishes prefer to settle on patch-reefs within lagoons, and whether predation rates differ between juveniles using patch-reef versus rubble.

Fourth, small differences in density may be augmented by aggregation tendencies of settlers. Both Acanthurus spp. (Shulman 1985a, Risk 1998) and Haemulon spp. (Shulman 1985a) are attracted to sites already occupied by juvenile conspecifics.

In contrast to Acanthurus spp. and Haemulon spp., post-settlement and juvenile Sparisoma aurofrenatum and Scarus iserti preferentially use back-reef and, to some extent patch-reef, habitats. Juvenile $S$. aurofrenatum prefer pavement and coral rubble (Tolimieri 1998a), or a mixture of coral and algae (Overholtzer \& Motta 1999). High site-fidelity, increasing the area of home ranges as an individual grows, and high levels of intra-specific aggression, may impose a minimum size limit on potential habitat for $S$. aurofrenatum. The restricted area of most lagoon patch-reefs and rubble locations limits the utility of these lagoon habitats as nurseries for $S$. aurofrenatum.

Behavior and distribution among habitats of Scarus iserti among reef habitats is determined in part by the distribution of its primary food source, ephemeral patches of filamentous microalgae and diatoms that grow on coral rubble (Clifton 1991). On back-reefs, juveniles preferentially utilize coral rubble, especially Porites spp. (Tolimieri 1998a), while on patch-reefs juveniles reside in areas of mixed coral and rubble (Overholtzer \& Motta 1999). Individuals have a limited home range and do not migrate to other reefs (Ogden \& Buckman 1973). Finally, like many scarids, S. iserti are active diurnally, and require night-time shelter. Thus, a habitat must provide suitable feeding substrate over enough area to support multiple individuals and shelter for sleeping to be appropriate for $S$. iserti. The lagoon habitats we studied are either too small in area (rubble and small patch-reefs) or do not provide adequate shelter (algal plain, seagrass, and sand), so only the back-reef and large lagoon patch-reefs meet the requirements of $S$. iserti.

In conclusion, although some reef-associated fishes (e.g. Sparisoma aurofrenatum and Scarus iserti) show little affinity for lagoon habitats, many other fishes of St. Croix utilize lagoon patch-reef and rubble habitats as nurseries (e.g. Acanthurus spp. and Haemulon spp.). Reef fishes that use lagoon nurseries must pass over the reef proper to reach these habitats. Lagoon patch-reefs and rubble must provide advantages to juveniles that compensate for the added energy expense and predation experienced by these fisheswhen they search for these habitats as larvae, and again when they return to the reef during the juvenile to adult transition. For these species, post-settlement processes greatly modify settlement patterns, weakening the relationship between larval supply and postsettlement abundance. Additional research is needed to determine the extent to which lagoon nurseries contribute to populations of adults on adjacent reefs. For species that settle into and use similar habitats throughout their demersal life stages, the abundance of adults is likely to have a stronger correlation with settlement patterns.

While settlement peaked during summer, some settlement occurred throughout the year. Often, patterns of habitat preference by settlers and habitat-use by juveniles differed by season. It is not known how priority effects (Shulman et al. 1983), differential mortality based on numbers or size of individuals (Sogard 1997), or the condition of settling and post-settlement fishes (McCormick 1998) vary among peak and non-peak periods of settlement. Considering that much of the research of settling and juvenile fishes in the Caribbean has taken place during the summer, but that settlement 
occurs throughout the year, future research may focus on the relative importance of processes affecting settling and juvenile fishes throughout the year.

As managers address issues such as the placement and design of marine reserves, information on habitat utilization and life-history characteristics of coral reef fishes, as contained in this study, will become a vital part of the decision-making process. The use of lagoon habitats as nurseries by reef-associated fishes must be incorporated into any management plan.
Acknowledgements. This research was funded by a grant from NOAA/NMFS/Saltonstall-Kennedy program (NA97 FD0070) to J.P.E., 2 Sigma Xi Grants In Aid of Research to A.J.A., a University of Massachusetts Boston Dissertation Support Grant to A.J.A., and generous support from the Biology Department of the University of Massachusetts Boston. We thank K. Gloger for excellent work in the field, G. Skomal for lodging on St. Croix, Dave Ward of Seaward Research for field support, the St. Croix Yacht Club, and the staff at Anchor Dive Center for excellent care and service. This research was done in partial fulfillment of the requirements for a $\mathrm{PhD}$ by A.J.A.

Appendix 1. Species recorded in back-reef and lagoon censuses by size class and habitat. Data pooled across all sites and census periods. sm: small $(<3 \mathrm{~cm})$, md: medium $(3$ to $5 \mathrm{~cm})$, lg: large $(>5 \mathrm{~cm})$. Values are percent relative abundance of the species in that habitat-size class (i.e. number of individuals from that species as a percentage of all fishes of all species of that size class in that habitat)

\begin{tabular}{|c|c|c|c|c|c|c|c|c|c|c|c|c|c|c|c|c|c|c|}
\hline \multirow[t]{2}{*}{ Family/Species } & \multicolumn{3}{|c|}{ Patch-reef } & \multicolumn{3}{|c|}{ Rubble } & \multicolumn{3}{|c|}{ Seagrass } & \multicolumn{3}{|c|}{ Algal plain } & \multicolumn{3}{|c|}{ Sand } & \multicolumn{3}{|c|}{ Back-reef } \\
\hline & $\mathrm{sm}$ & md & $\lg$ & $\mathrm{sm}$ & md & $\lg$ & $\mathrm{sm}$ & md & $\lg$ & $\mathrm{sm}$ & md & $\lg$ & $\mathrm{sm}$ & md & $\lg$ & $\mathrm{sm}$ & md & $\lg$ \\
\hline \multicolumn{19}{|l|}{ Synodontidae } \\
\hline Synodus saurus & 0 & 0 & 0 & 0 & 0 & 0 & 0 & 0 & 0 & 0 & 0 & 0 & 0 & 0 & 0 & 0 & 0 & $<0.01$ \\
\hline \multicolumn{19}{|l|}{ Holocentridae } \\
\hline Holocentrus adscensionis & 0 & 0 & 0.87 & 0 & 0 & 1.41 & 0 & 0 & 0 & 0 & 0 & 0 & 0 & 0 & 0 & 0.03 & 0 & 1.25 \\
\hline H. curuscus & 0 & 0.05 & 0.06 & 0 & 0 & 0 & 0 & 0 & 0 & 0 & 0 & 0 & 0 & 0 & 0 & 0.03 & 0.01 & 0.05 \\
\hline H. marianus & 0 & 0 & 0.74 & 0 & 0.4 & 1.69 & 0 & 0 & 0 & 0 & 0 & 0 & 0 & 0 & 0 & $<0.01$ & 0 & 0.93 \\
\hline$H$. vexillarius & 0 & 0.05 & 0 & 0 & 0 & 0 & 0 & 0 & 0 & 0 & 0 & 0 & 0 & 0 & 0 & 0.01 & $<0.01$ & 0.02 \\
\hline Myripristis jacobus & 0 & 0 & 0.23 & 0 & 0 & 0 & 0 & 0 & 0 & 0 & 0 & 0 & 0 & 0 & 0 & 0.02 & 0.01 & 0.47 \\
\hline \multicolumn{19}{|l|}{ Aulostomidae } \\
\hline Aulostomus maculatus & 0 & 0 & 0.13 & 0 & 0 & 0.28 & 0 & 0 & 0 & 0 & 0 & 0 & 0 & 0 & 0 & 0 & 0 & 0.14 \\
\hline \multicolumn{19}{|l|}{ Serranidae } \\
\hline Epinephelus adscensionis & 0 & 0 & 0.06 & 0 & 0 & 0 & 0 & 0 & 0 & 0 & 0 & 0 & 0 & 0 & 0 & 0 & 0 & 0.04 \\
\hline E. cruentatus & 0 & 0 & 0.1 & 0 & 0 & 0 & 0 & 0 & 0 & 0 & 0 & 0 & 0 & 0 & 0 & 0 & 0 & 0.04 \\
\hline E. fulvus & 0 & 0 & 0 & 0 & 0 & 0 & 0 & 0 & 0 & 0 & 0 & 0 & 0 & 0 & 0 & 0 & 0 & 0.01 \\
\hline E. guttatus & 0 & 0 & 0.51 & 0 & 0 & 0 & 0 & 0 & 0 & 0 & 0 & 0.32 & 0 & 0 & 0 & 0 & 0 & 0.25 \\
\hline E. striatus & 0 & 0 & 0.03 & 0 & 0 & 0 & 0 & 0 & 0 & 0 & 0 & 0 & 0 & 0 & 0 & 0 & 0 & $<0.01$ \\
\hline Hypoplectrus chlorurus & 0 & 0 & 0.1 & 0 & 0 & 0 & 0 & 0 & 0 & 0 & 0 & 0 & 0 & 0 & 0 & 0 & 0 & 0.01 \\
\hline H. nigricans & 0 & 0 & 0.03 & 0 & 0 & 0 & 0 & 0 & 0 & 0 & 0 & 0 & 0 & 0 & 0 & $<0.01$ & 0 & 0.04 \\
\hline H. puella & 0 & 0 & 0.32 & 0 & 0 & 0 & 0 & 0 & 0 & 0 & 0 & 0 & 0 & 0 & 0 & 0.03 & $<0.01$ & 0.06 \\
\hline H. unicolor & 0 & 0.1 & 0.1 & 0 & 0.19 & 0 & 0 & 0 & 0 & 0 & 0 & 0 & 0 & 0 & 0 & 0.03 & 0.01 & 0.08 \\
\hline Serranus tabacarius & 0.06 & 0 & 0 & 0 & 0 & 0 & 0 & 0 & 0 & 0 & 0 & 0 & 0 & 0 & 0 & 0 & $<0.01$ & 0 \\
\hline S. tigrinus & 0 & 0.15 & 0.68 & 0.16 & 0.37 & 0 & 0 & 0 & 0 & 0 & 0 & 0 & 0 & 9.09 & 0 & 0.29 & 0.07 & 1.11 \\
\hline Rypticus saponaceus & 0 & 0 & 0.03 & 0 & 0 & 0 & 0 & 0 & 0 & 0 & 0 & 0 & 0 & 0 & 0 & 0 & 0 & $<0.01$ \\
\hline \multicolumn{19}{|l|}{ Grammatidae } \\
\hline Gramma loreto & 0.13 & 0.1 & 0 & 0 & 0 & 0 & 0 & 0 & 0 & 0 & 0 & 0 & 0 & 0 & 0 & $<0.01$ & 0 & $<0.01$ \\
\hline \multicolumn{19}{|l|}{ Priacanthidae } \\
\hline Priacanthus cruentatus & 0 & 0 & 0 & 0 & 0 & 0 & 0 & 0 & 0 & 0 & 0 & 0 & 0 & 0 & 0 & 0 & 0 & 0.04 \\
\hline \multicolumn{19}{|l|}{ Malacanthidae } \\
\hline Malacanthus plumieri & 0 & 0.05 & 0.03 & 0 & 0 & 0 & 0 & 0 & 0.11 & 0 & 0 & 0.65 & 0 & 0 & 3.85 & 0 & $<0.01$ & 0.01 \\
\hline \multicolumn{19}{|l|}{ Lutjanidae } \\
\hline Lutjanus analis & 0 & 0 & 0.06 & 0 & 0 & 0 & 0 & 0 & 0.22 & 0 & 0 & 0.32 & 0 & 0 & 3.85 & 0 & 0 & $<0.01$ \\
\hline L. apodus & 0 & 0 & 0.16 & 0 & 0 & 0 & 0 & 0 & 0 & 0 & 0 & 0 & 0 & 0 & 0 & 0 & 0 & 0.21 \\
\hline L. mahogoni & 0.06 & 0 & 0.26 & 0.93 & 0 & 0 & 0.17 & 0.2 & 0 & 1.0 & 0.19 & 0.32 & 11.1 & 0 & 0 & 0.07 & 0.07 & 0.52 \\
\hline L. synagris & 0 & 0 & 0 & 0 & 0 & 0 & 0 & 0 & 0 & 0 & 0 & 0 & 0 & 0 & 0 & 0 & 0 & $<0.01$ \\
\hline Ocyurus chrysurus & 0 & 0.05 & 1.45 & 0 & 0.2 & 1.97 & 0 & 1.99 & 5.47 & 0.45 & 0.38 & 1.62 & 0 & 0 & 7.69 & 0.02 & 0 & 0.77 \\
\hline \multicolumn{19}{|l|}{ Gerreidae } \\
\hline Gerres cinereus & 0 & 0 & 0.55 & 0 & 0 & 0.28 & 0 & 0 & 1.12 & 0 & 0 & 0.65 & 0 & 0 & 3.85 & 0 & 0 & 0.39 \\
\hline Eucinostomus jonesi & 0 & 0 & 0 & 0 & 0 & 0 & 0 & 0 & 0 & 0 & 0 & 0 & 0 & 0 & 3.85 & 0 & 0 & 0 \\
\hline Haemulidae & & & & & & & & & & & & & & & & & & \\
\hline Anisotremus virginicus & 0 & 0 & 0 & 0 & 0 & 0 & 0 & 0 & 0 & 0 & 0 & 0 & 0 & 0 & 0 & 0 & 0 & $<0.01$ \\
\hline Haemulon aurolineatum ${ }^{\mathrm{a}}$ & 0 & 0.3 & 2.54 & 1.40 & 0 & 0.28 & 0 & 0 & 0 & 0 & 0 & 0 & 0 & 0 & 0 & 0.21 & 0.03 & 0.05 \\
\hline H. carbonarium ${ }^{a}$ & 0 & 0 & 0.26 & 0 & 0 & 0.28 & 0 & 0 & 0 & 0 & 0 & 0 & 0 & 0 & 0 & 0.01 & 0 & 0.49 \\
\hline H. chrysargyreum ${ }^{a}$ & 0 & 0 & 0 & 0 & 0 & 0 & 0 & 0 & 0 & 0 & 0 & 0 & 0 & 0 & 0 & 0 & $<0.01$ & 0.02 \\
\hline H. flavolineatum ${ }^{a}$ & 1.93 & 4.16 & 7.68 & 0 & 4.16 & 1.13 & 0 & 0 & 0 & 0 & 0 & 0.97 & 0 & 0 & 0 & 6.86 & 2.58 & 12.9 \\
\hline H. macrostomum ${ }^{a}$ & 0 & 0 & 0.19 & 0 & 0 & 0 & 0 & 0 & 0 & 0 & 0 & 0 & 0 & 0 & 0 & 0 & 0 & $<0.01$ \\
\hline
\end{tabular}


Appendix 1 (continued)

\begin{tabular}{|c|c|c|c|c|c|c|c|c|c|c|c|c|c|c|c|c|c|c|}
\hline \multirow[t]{2}{*}{ Family/Species } & \multicolumn{3}{|c|}{ Patch-reef } & \multicolumn{3}{|c|}{ Rubble } & \multicolumn{3}{|c|}{ Seagrass } & \multicolumn{3}{|c|}{ Algal plain } & \multicolumn{3}{|c|}{ Sand } & \multicolumn{3}{|c|}{ Back-reef } \\
\hline & $\mathrm{sm}$ & md & $\lg$ & $\mathrm{sm}$ & md & $\lg$ & $\mathrm{sm}$ & md & $\lg$ & $\mathrm{sm}$ & md & $\lg$ & $\mathrm{sm}$ & md & $\lg$ & $\mathrm{sm}$ & & $\lg$ \\
\hline Haemulidae (continued) & & & & & & & & & & & & & & & & & & \\
\hline H. plumieri ${ }^{\mathrm{a}}$ & 0.26 & 0.9 & 2.32 & 3.26 & 1.39 & 0 & 0 & 0 & 2.34 & 0 & 0 & 0 & 0 & 0 & 0 & 0.06 & 0.01 & 2.12 \\
\hline H. sciurus ${ }^{\mathrm{a}}$ & 0 & 0 & 0.1 & 0 & 0 & 0 & 0 & 0 & 0 & 0 & 0 & 0 & 0 & 0 & 0 & 0.01 & 0 & 0.08 \\
\hline Haemulon spp. ${ }^{a}$ & 40.2 & 8.51 & 0.48 & 21.2 & 0 & 0 & 64.5 & 0 & 0 & 82.6 & 0 & 0 & 0 & 0 & 0 & 3.96 & 18.9 & 0 \\
\hline Sciaenidae & & & & & & & & & & & & & & & & & & \\
\hline Equetus acuminatus & 0 & 0 & 0 & 0 & 0.2 & 0 & 0 & 0 & 0 & 0 & 0 & 0 & 0 & 0 & 0 & 0 & 0 & $<0.01$ \\
\hline E. punctatus & 0.06 & 0.2 & 0.03 & 0 & 0 & 0 & 0 & 0 & 0 & 0 & 0 & 0 & 0 & 0 & 0 & 0 & 0.01 & 0.01 \\
\hline Mullidae & & & & & & & & & & & & & & & & & & \\
\hline Mulloidichthys martinicus & 0 & 0 & 1.83 & 0 & 0 & 0.28 & 0 & 0 & 0 & 0 & 0 & 0 & 0 & 0 & 0 & 0 & 0 & 1.72 \\
\hline Pseudupeneus maculatus & 0 & 0 & 5.24 & 0.31 & 0.4 & 1.97 & 0 & 5.38 & 29.0 & 0 & 0.96 & 3.88 & 0 & 0 & 23.1 & 0.13 & 0.01 & 1.16 \\
\hline Pempheridae & & & & & & & & & & & & & & & & & & \\
\hline Pempheris schomburgki & 0 & 0 & 0 & 0 & 0 & 0 & 0 & 0 & 0 & 0 & 0 & 0 & 0 & 0 & 0 & 0 & 0 & $<0.01$ \\
\hline Kyphosidae & & & & & & & & & & & & & & & & & & \\
\hline Kyphosus sectatrix & 0 & 0 & 0 & 0 & 0 & 0 & 0 & 0 & 0 & 0 & 0 & 0 & 0 & 0 & 0 & 0 & 0 & 0.01 \\
\hline Chaetodontidae & & & & & & & & & & & & & & & & & & \\
\hline Chaetodon capistratus & 0.84 & 0.6 & 1.29 & 0.93 & 1.39 & 0.28 & 0 & 0 & 0 & 0 & 0 & 0 & 0 & 0 & 0 & 0.39 & 0.29 & 0.39 \\
\hline C. ocellatus & 0 & 0 & 0 & 0 & 0 & 0 & 0 & 0 & 0 & 0 & 0 & 0 & 0 & 0 & 0 & $<0.01$ & $<0.01$ & 0 \\
\hline C. striatus & 0.13 & 0.35 & 0.61 & 0.47 & 0.37 & 0.56 & 0 & 0 & 0 & 0.09 & 0 & 0 & 0 & 0 & 0 & 0.1 & 0.04 & 0.34 \\
\hline Pomacanthidae & & & & & & & & & & & & & & & & & & \\
\hline Holacanthus ciliaris & 0 & 0.1 & 0 & 0 & 0 & 0 & 0 & 0 & 0 & 0 & 0 & 0 & 0 & 0 & 0 & 0 & $<0.01$ & $<0.01$ \\
\hline H. tricolor & 0 & 0 & 0 & 0 & 0 & 0 & 0 & 0 & 0 & 0 & 0 & 0 & 0 & 0 & 0 & $<0.01$ & $<0.01$ & $>0.01$ \\
\hline Pomacanthus paru & 0 & 0.05 & 0.13 & 0 & 0 & 0 & 0 & 0 & 0 & 0 & 0 & 0 & 0 & 0 & 0 & $<0.01$ & $<0.01$ & 0.03 \\
\hline Pomacentridae & & & & & & & & & & & & & & & & & & \\
\hline Abudefduf saxatilis & 0.13 & 0 & 0.1 & 0 & 0 & 0 & 0 & 0 & 0 & 0 & 0 & 0 & 0 & 0 & 0 & 0.07 & 0.12 & 0.75 \\
\hline A. taurus & 0 & 0 & 0 & 0 & 0 & 0 & 0 & 0 & 0 & 0 & 0 & 0 & 0 & 0 & 0 & 0 & 0 & $<0.01$ \\
\hline Chromis cyanea & 0.06 & 0.1 & 0.84 & 0 & 0 & 0.28 & 0 & 0 & 0 & 0 & 0 & 0 & 0 & 0 & 0 & 0.25 & 0.31 & 0.25 \\
\hline C. multilineata & 0 & 1.6 & 1.29 & 0 & 0 & 0 & 0 & 0 & 0 & 0 & 0 & 0 & 0 & 0 & 0 & 0.75 & 0.13 & 0.7 \\
\hline Microspathodon chrysurus & 0.06 & 0.05 & 0.23 & 0 & 0 & 0.28 & 0 & 0 & 0 & 0 & 0 & 0 & 0 & 0 & 0 & 0.04 & 0.02 & 0.58 \\
\hline Stegastes diencaeus & 0.19 & 0.45 & 0.67 & 0 & 0 & 0 & 0 & 0 & 0 & 0 & 0 & 0 & 0 & 0 & 0 & 0.68 & 0.71 & 1.74 \\
\hline S. fuscus & 0.26 & 0.3 & 1.32 & 0.16 & 0 & 0 & 0 & 0 & 0 & 0 & 0 & 0 & 0 & 0 & 0 & 0.5 & 0.19 & 2.33 \\
\hline S. leucostictus & 7.48 & 11.1 & 5.56 & 19.2 & 17.0 & 11.8 & 0.17 & 0.2 & 0.11 & 0.36 & 1.35 & 0 & 0 & 0 & 0 & 11.5 & 8.78 & 6.55 \\
\hline S. partitus & 7.22 & 7.06 & 0.8 & 5.42 & 4.95 & 1.69 & 0 & 0.2 & 0 & 0 & 0 & 0 & 0 & 0 & 0 & 5.79 & 4.15 & 0.85 \\
\hline S. planifrons & 1.68 & 1.35 & 2.34 & 0 & 0 & 0.28 & 0 & 0 & 0 & 0 & 0 & 0 & 0 & 0 & 0 & 0.6 & 0.65 & 0.88 \\
\hline S. variabilis & 0 & 0 & 0.06 & 0 & 0 & 0 & 0 & 0 & 0 & 0 & 0 & 0 & 0 & 0 & 0 & 0.01 & $<0.01$ & 0.03 \\
\hline Cirrhitidae & & & & & & & & & & & & & & & & & & \\
\hline Amblycirrhitus pinos & 0 & 0 & 0 & 0 & 0 & 0 & 0 & 0 & 0 & 0 & 0 & 0 & 0 & 0 & 0 & $<0.01$ & 0 & $<0.01$ \\
\hline Labridae & & & & & & & & & & & & & & & & & & \\
\hline Bodianus rufus & 0 & 0 & 0.23 & 0 & 0 & 0 & 0 & 0 & 0 & 0 & 0 & 0 & 0 & 0 & 0 & 0.02 & 0.04 & 0.06 \\
\hline Halichoeres bivittatus & 9.48 & 17.8 & 12.9 & 27.8 & 44.6 & 42.8 & 16.8 & 49.4 & 39.6 & 12.8 & 73.9 & 68.6 & 83.3 & 36.4 & 26.9 & 24.8 & 24.4 & 15.2 \\
\hline H. cyanocephalus & 0 & 0 & 0 & 0 & 0 & 0 & 0 & 0 & 0 & 0 & 0 & 0 & 0 & 0 & 0 & 0 & $<0.01$ & 0 \\
\hline H. garnoti & 0.39 & 0.45 & 1.22 & 0 & 0 & 0 & 0 & 0 & 0 & 0 & 0 & 0 & 0 & 0 & 0 & 0.5 & 0.21 & 1.27 \\
\hline H. maculipinna & 0.06 & 0.35 & 0.77 & 0.16 & 0.4 & 0.85 & 0 & 0 & 0.11 & 0.09 & 0 & 0 & 0 & 0 & 0 & 2.36 & 0.52 & 3.35 \\
\hline H. poeyi & 0.13 & 0.85 & 1.77 & 0 & 0.4 & 1.13 & 0.17 & 2.59 & 2.01 & 0.09 & 0.77 & 2.91 & 0 & 0 & 0 & 0.69 & 0.29 & 1.38 \\
\hline H. radiatus & 0.06 & 0.25 & 0.71 & 0 & 0 & 0 & 0 & 0 & 0.11 & 0 & 0 & 0 & 0 & 0 & 0 & 0.52 & 0.27 & 0.75 \\
\hline Hemipteronotus martinicensis & $s 0$ & 0 & 0 & 0 & 0 & 0 & 0 & 0 & 0 & 0.18 & 0.77 & 3.56 & 0 & 9.09 & 11.5 & 0 & 0 & 0 \\
\hline H. splendens & 0 & 0 & 0.03 & 0 & 0 & 0 & 0 & 0 & 0.22 & 0 & 0 & 0.32 & 0 & 0 & 0 & 0 & 0 & 0 \\
\hline Thalassoma bifasciatum & 6.19 & 16.6 & 8.39 & 0.31 & 1.39 & 6.2 & 0 & 0 & 0 & 0 & 0 & 0 & 0 & 0 & 0 & 13.6 & 8.23 & 6.73 \\
\hline Scaridae & & & & & & & & & & & & & & & & & & \\
\hline Cryptotomus roseus & 0 & 0 & 0 & 0 & 0 & 0 & 1.9 & 3.39 & 0.56 & 0.27 & 1.73 & 2.59 & 0 & 0 & 0 & 0.03 & 0.01 & 0.01 \\
\hline Scarus iserti & 9.35 & 10.1 & 7.68 & 0 & 0 & 0 & 0.17 & 0 & 0 & 0 & 0 & 0 & 0 & 0 & 0 & 13.6 & 16.6 & 9.49 \\
\hline S. taeniopterus & 2.12 & 0.9 & 0.13 & 0.31 & 1.19 & 1.41 & 0 & 0 & 0 & 0.2 & 0 & 0 & 0 & 0 & 0 & 0.25 & 0.73 & 0.12 \\
\hline S. vetula & 0 & 0 & 0 & 0 & 0 & 0 & 0 & 0 & 0 & 0 & 0 & 0 & 0 & 0 & 0 & 0.02 & 0 & 0.5 \\
\hline Sparisoma atomarium & 0.26 & 0.5 & 0 & 0.31 & 0 & 0 & 0 & 0.2 & 0 & 0 & 0 & 0 & 0 & 0 & 0 & 0.36 & 0.3 & 0.06 \\
\hline S. aurofrenatum & 1.61 & 3.21 & 4.15 & 1.24 & 1.39 & 1.69 & 0 & 0 & 0 & 0 & 0 & 0 & 0 & 0 & 0 & 2.97 & 3.53 & 2.88 \\
\hline S. chrysopterum & 1.41 & 0.2 & 0.45 & 0 & 0 & 0 & 0 & 0 & 0 & 0 & 0 & 0 & 0 & 0 & 0 & $<0.01$ & $<0.01$ & 0.22 \\
\hline S. radians & 0 & 0.8 & 0.29 & 0.16 & 0.4 & 0.85 & 8.14 & 33.1 & 14.9 & 1.09 & 9.41 & 4.53 & 5.56 & 36.4 & 3.85 & 0.23 & 1.88 & 0.09 \\
\hline S. rubripinne & 0 & 0 & 0.25 & 0 & 0 & 0 & 0 & 0 & 0 & 0 & 0 & 0 & 0 & 0 & 0 & 0.01 & 0.01 & 0.32 \\
\hline$S$. viride & 1.81 & 1.25 & 1.48 & 0 & 0.2 & 1.13 & 0.17 & 0 & 0 & 0 & 0 & 0 & 0 & 0 & 0 & 1.66 & 2.15 & 2.11 \\
\hline Unknown Scaridae & 0.39 & 0.4 & 0 & 0.16 & 0 & 0 & 0 & 0 & 0 & 0 & 0 & 0 & 0 & 0 & 0 & 0.14 & 0 & 0 \\
\hline Acanthuridae & & & & & & & & & & & & & & & & & & \\
\hline Acanthurus bahianus ${ }^{\mathrm{b}}$ & 4.9 & 5.8 & 10.8 & 13.9 & 16.0 & 10.4 & 7.62 & 2.19 & 2.9 & 0.45 & 0 & 0 & 0 & 0 & 0 & 4.26 & 2.47 & 8.82 \\
\hline A. chirurgus $^{\mathrm{b}}$ & 0.06 & 0.10 & 2.48 & 1.55 & 2.57 & 0.85 & 0 & 0 & 0 & 0.18 & 0 & 0 & 0 & 0 & 0 & 0.42 & 0.25 & 2.02 \\
\hline A. coeruleus & 0.64 & 1.7 & 3.47 & 0.16 & 0.2 & 1.13 & 0 & 0 & 0 & 0 & 0 & 0 & 0 & 0 & 0 & 1.01 & 0.9 & 3.36 \\
\hline
\end{tabular}


Appendix 1 (continued)

\begin{tabular}{|c|c|c|c|c|c|c|c|c|c|c|c|c|c|c|c|c|c|c|}
\hline \multirow[t]{2}{*}{ Family/Species } & \multicolumn{3}{|c|}{ Patch-reef } & \multicolumn{3}{|c|}{ Rubble } & \multicolumn{3}{|c|}{ Seagrass } & \multicolumn{3}{|c|}{ Algal plain } & \multicolumn{3}{|c|}{ Sand } & \multicolumn{3}{|c|}{ Back-reef } \\
\hline & sm & md & $\lg$ & $\mathrm{sm}$ & md & $\lg$ & sm & md & $\lg$ & $\mathrm{sm}$ & md & $\lg$ & sm & md & $\lg$ & $\mathrm{sm}$ & md & $\lg$ \\
\hline \multicolumn{19}{|l|}{ Balistidae } \\
\hline Aluterus scriptus & 0 & 0 & 0 & 0 & 0 & 0 & 0 & 0 & 0 & 0 & 0 & 0 & 0 & 0 & 0 & 0 & 0 & $<0.01$ \\
\hline Cantherhines pullus & 0 & 0 & 0.03 & 0 & 0 & 0 & 0 & 0 & 0 & 0 & 0 & 0 & 0 & 0 & 0 & $<0.01$ & 0 & 0.12 \\
\hline Monocanthus spp. & 0 & 0.05 & 0 & 0 & 0.2 & 0.28 & 0 & 0.2 & 0.22 & 0.09 & 0.19 & 0 & 0 & 0 & 0 & $<0.01$ & 0 & 0 \\
\hline Balistes vetula & 0 & 0 & 0 & 0 & 0 & 0 & 0 & 0 & 0 & 0 & 0 & 0.64 & 0 & 0 & 0 & 0 & 0 & 0 \\
\hline \multicolumn{19}{|l|}{ Ostraciidae } \\
\hline Lactophrys bicaudalis & 0 & 0 & 0.06 & 0 & 0 & 0 & 0 & 0 & 0.22 & 0 & 0 & 0.32 & 0 & 0 & 0 & 0 & 0 & $<0.01$ \\
\hline L. polygonia & 0 & 0 & 0 & 0 & 0 & 0 & 0 & 0 & 0 & 0 & 0 & 0 & 0 & 0 & 0 & 0.01 & 0 & $<0.01$ \\
\hline L. quadricornis & 0 & 0 & 0 & 0 & 0 & 0 & 0 & 0 & 0 & 0 & 0 & 0 & 0 & 0 & 0 & 0 & 0 & $<0.01$ \\
\hline L. triqueter & 0 & 0 & 0 & 0 & 0 & 0 & 0 & 0 & 0 & 0 & 0 & 0 & 0 & 0 & 0 & 0 & $<0.01$ & 0.01 \\
\hline \multicolumn{19}{|l|}{ Tetraodontidae } \\
\hline Canthigaster rostrata & 0.39 & 0.85 & 0.32 & 0.16 & 0 & 0 & 0.17 & 0.4 & 0.33 & 0 & 0.58 & 0.97 & 0 & 0 & 0 & 0.07 & 0.08 & 0.03 \\
\hline Diodon hystrix & 0 & 0 & 0 & 0 & 0 & 0 & 0 & 0 & 0 & 0 & 0 & 0 & 0 & 0 & 0 & 0 & 0 & 0.04 \\
\hline Sphoeroides spengleri & 0 & 0 & 0 & 0 & 0 & 0 & 0 & 0.6 & 0.22 & 0 & 0.19 & 1.29 & 0 & 0 & 0 & 0 & 0 & 0 \\
\hline
\end{tabular}

\section{LITERATURE CITED}

Abrams PA (1984) Recruitment, lotteries, and coexistence in coral reef fish. Am Nat 123:44-55

Ault TR, Johnson CR (1998) Spatially and temporally predictable fish communities on coral reefs. Ecol Monogr 68(1):25-50

Beets J (1997) Effects of a predatory fish on the recruitment and abundance of Caribbean coral reef fishes. Mar Ecol Prog Ser 148:11-21

Beukers JS, Jones GP (1997) Habitat complexity modifies the impact of piscivores on a coral reef population. Oecologia 114:50-59

Bohnsack JA, Talbot FH (1980) Species-packing by reef fishes on Australian and Caribbean reefs: an experimental approach. Bull Mar Sci 30(3):710-723

Caselle JE (1999) Early post-settlement mortality in a coral reef fish and its effect on local population size. Ecol Monogr 69:177-194

Caselle JE, Warner RR (1996) Variability in recruitment of coral reef fishes: the importance of habitat at two spatial scales. Ecology $77(8): 2488-2504$

Clifton KE (1991) Subordinate group members act as foodfinders within striped parrotfish territories. J Exp Mar Biol Ecol 145:141-148

Doherty PJ (1982) Some effects of density on the juveniles of two species of tropical, territorial damselfishes. J Exp Mar Biol Ecol 65:249-261

Doherty PJ (1983) Tropical territorial damselfishes: is density limited by aggression or recruitment? Ecology 64:176-190

Doherty PJ, Fowler AJ (1994) An empirical test of recruitment limitation in a coral reef fish. Science 263:935-939

Ebersole JP (1985) Niche separation of two damselfish species by aggression and differential microhabitat utilization. Ecology 66:14-20

Eggleston DB (1995) Recruitment in Nassau grouper, Epinephelus striatus: post-settlement abundance, microhabitat features, and ontogenetic habitat shifts. Mar Ecol Prog Ser 124:9-22

Eggleston DB, Lipcius RN, Grover JJ (1997) Predator and shelter-size effects on coral reef fish and spiny lobster. Mar Ecol Prog Ser 149:43-59

Forrester GE (1995) Strong density-dependent survival and recruitment regulate the abundance of coral reef fish. Oecologia 103:275-282

Forrester GE (1999) The influence of adult density on larval settlement in a coral reef fish, Coryphopterus glaucofraenum. Coral Reefs 18:85-89

Fowler AJ, Doherty PJ, Williams DMcB (1992) Multi-scale analysis of recruitment of a coral reef fish on the Great Barrier Reef. Mar Ecol Prog Ser 82:131-141

Frederick JL (1997) Post-settlement movement of coral reef fishes and bias in survival estimates. Mar Ecol Prog Ser 150:65-74

Glass GV, Peckham PD, Sanders JR (1972) Consequences of failure to meet assumptions underlying the fixed effects analyses of variance and covariance. Rev Educ Res 42(3): $237-288$

Green AL (1996) Spatial, temporal and ontogenetic patterns of habitat use by coral reef fishes (family Labridae). Mar Ecol Prog Ser 133:1-11

Hixon MA (1991) Predation as a process structuring coral reef fish communities. In: Sale PF (ed) The ecology of fishes on coral reefs. Academic Press, San Diego, p 475-508

Hixon MA, Beets JP (1989) Shelter characteristics and Caribbean fish assemblages: experiments with artificial reefs. Bull Mar Sci 44:666-680

Hixon MA, Beets JP (1993) Predation, prey refuges, and the structure of coral-reef fish assemblages. Ecol Monogr 63(1):77-101

Jones GP (1991) Postrecruitment processes in the ecology of coral reef fish populations: a multifactorial perspective. In: Sale PF (ed) The ecology of fishes on coral reefs. Academic Press, New York, p 294-328

Kaufman L, Ebersole J, Beets J, McIvor CC (1992) A key phase in the recruitment dynamics of coral reef fishes: post-settlement transition. Environ Biol Fish 34:109-118

Kerrigan BA (1994) Post-settlement growth and body composition in relation to food availability in a juvenile tropical reef fish. Mar Ecol Prog Ser 111:7-15 
Lawson GL, Kramer DL, Hunte W (1999) Size-related habitat use and schooling behavior in two species of surgeonfish (Acanthurus bahianus and A. coeruleus) on a fringing reef in Barbados, West Indies. Environ Biol Fish 54:19-33

Levin P, Petrik R, Malone J (1997a) Interactive effects of habitat selection, food supply, and predation on recruitment of an estuarine fish. Oecologia 112:55-63

Levin PS, Chiasson W, Green JM (1997b) Geographic differences in recruitment and population structure of a temperate reef fish. Mar Ecol Prog Ser 161:23-35

Mahon R, Mahon SD (1994) Structure and resilience of a tidepool fish assemblage in Barbados. Environ Biol Fish 41: 171-190

McCormick MI (1998) Condition and growth in reef fish at settlement: is it important? Aust J Ecol 23:258-264

McCormick MI (1999) Delayed metamorphosis of a tropical reef fish (Acanthurus triostegus): a field experiment. Mar Ecol Prog Ser 176:25-38

McCormick MI, Makey LJ (1997) Post-settlement transition in coral reef fishes: overlooked complexity in niche shifts. Mar Ecol Prog Ser 153:247-257

Munro JL, Gaut VC, Thompson R, Reeson PH (1973) The spawning seasons of Caribbean reef fishes. J Fish Biol 5: 69-84

Nagelkerken I, van der Velde G, Gorissen MW, Meijer GJ, van't Hof T, den Hartog C (2000) Importance of mangroves, seagrass beds and the shallow coral reef as a nursery for important coral reef fishes, using visual census technique. Estuar Coast Shelf Sci 51: 31-44

Ogden JC, Buckman NS (1973) Movements, foraging groups, and diurnal migrations of the striped parrotfish Scarus croicensis Bloch (Scaridae). Ecology 53(3):589-596

Overholtzer KL, Motta PJ (1999) Comparative resource use by juvenile parrotfishes in the Florida Keys. Mar Ecol Prog Ser 177:177-187

Risk A (1997) Effects of habitat on the settlement and postsettlement success of the ocean surgeonfish Acanthurus bahianus. Mar Ecol Prog Ser 161:51-59

Risk A (1998) The effects of interactions with reef residents on the settlement and subsequent persistence of ocean surgeonfish, Acanthurus bahianus. Environ Biol Fish 51: 377-389

Robertson DR (1988) Abundances of surgeonfishes on patchreefs in Caribbean Panama: due to settlement, or postsettlement events? Mar Biol 97:495-501

Robertson DR, Polunin NVC, Leighton K (1979) The behavioral ecology of three Indian Ocean surgeonfishes (Acanthurus lineatus, A. leucosternum, and Zebrasoma scopas): their feeding strategies, and social and mating systems. Environ Biol Fish 4:125-170

Sale PF (1982) Stock-recruitment relationships and regional coexistence in a lottery competitive system: a simulation study. Am Nat 120:139-159

Sale PF, Doherty PJ, Eckert GJ, Douglas WA, Ferrell KJ (1984) Large scale spatial and temporal variation in recruitment to fish populations on coral reefs. Oecologia 64:191-198

Sancho G, Ma D, Lobel PS (1997) Behavioral observations of an upcurrent reef colonization event by larval surgeonfish Ctenochaetus strigosus (Acanthuridae). Mar Ecol Prog Ser 153:311-315

Schmitt RJ, Holbrook SJ (1999) Settlement and recruitment of three damselfish species: larval delivery and competition for shelter space. Oecologia 118:76-86

Shulman MJ (1985a) Recruitment of coral reef fishes: effects of distribution of predators and shelter. Ecology 66(3): 1056-1066

Shulman MJ (1985b) Variability in recruitment of coral reef fishes. J Exp Mar Biol Ecol 89:205-219

Shulman MJ, Ogden JC (1987) What controls tropical reef fish populations: recruitment or benthic mortality? An example in the Caribbean reef fish Haemulon flavolineatum. Mar Ecol Prog Ser 39:233-242

Shulman MJ, Ogden JC, Ebersole JP, McFarland WN, Miller SL, Wolf NG (1983) Priority effects in the recruitment of juvenile coral reef fishes. Ecology 64(6):1508-1513

Smith CL, Tyler JC (1972) Space resource sharing in a coral reef fish community. Bull Los Angel Cty Mus Nat Hist 14: $125-170$

Sogard SM (1997) Size-selective mortality in the juvenile stage of teleost fishes: a review. Bull Mar Sci 60(3):1129-1157

Sponaugle S, Cowen RK (1996) Larval supply and patterns of recruitment for two Caribbean reef fishes, Stegastes partitus and Acanthurus bahianus. Mar Freshw Res 47: 433-447

Steele MA (1997a) Population regulation by post-settlement mortality in two temperate reef fishes. Oecologia 112: $64-74$

Steele M (1997b) The relative importance of processes affecting recruitment of two temperate reef fishes. Ecology 78(1):129-145

Stobutzki IC, Bellwood DR (1997) Sustained swimming abilities of the late pelagic stages of coral reef fishes. Mar Ecol Prog Ser 149:35-41

Sweatman HP, Robertson DR (1994) Grazing halos and predation on juvenile Caribbean surgeonfishes. Mar Ecol Prog Ser 111:1-6

Tolimieri N (1995) Effects of microhabitat characteristics on the settlement and recruitment of a coral reef fish at two spatial scales. Oecologia 102:52-63

Tolimieri N (1998a) Contrasting effects of microhabitat use on large-scale adult abundance in two families of Caribbean reef fishes. Mar Ecol Prog Ser 167:227-239

Tolimieri N (1998b) The relationship among microhabitat characteristics, recruitment and adult abundance in the stoplight parrotfish, Sparisoma viride, at three spatial scales. Bull Mar Sci 62(1):253-268

Tolimieri N, Sale PF, Nemeth RS, Gestring KB (1998) Replenishment of populations of Caribbean reef fishes: are spatial patterns of recruitment consistent through time? J Exp Mar Biol Ecol 230:55-71

Tupper M, Boutilier RG (1997) Effects of habitat on settlement, growth, predation risk and survival of a temperate reef fish. Mar Ecol Prog Ser 151:225-236

Tupper M, Juanes F (1999) Effects of a marine reserve on recruitment of grunts (Pisces: Haemulidae) at Barbados, West Indies. Environ Biol Fish 55:53-63

Victor BC (1983) Recruitment and population dynamics of a coral reef fish. Science 219:419-420

Victor BC (1986) Larval settlement and juvenile mortality in a recruitment-limited coral reef fish population. Ecol Monogr 56(2):145-160

Wilkinson L, Blank G, Gruber C (1996) Desktop data analysis with Systat. Prentice Hall, Upper Saddle River, NJ

Submitted: October 10, 2000; Accepted: May 31, 2001

Proofs received from author(s): January 28, 2002
Editorial responsibility: Otto Kinne (Editor),

Oldendorf/Luhe, Germany 